OCCASIONAL REVIEW

\title{
Inflammatory cells in the airways in COPD
}

\section{R O’Donnell, D Breen, S Wilson, R Diukanovic}

Thorax 2006;61:448-454. doi: 10.1136/thx.2004.024463

Airway inflammation is central to the pathogenesis of both airway remodelling and parenchymal destruction in chronic obstructive pulmonary disease (COPD). Neutrophils, macrophages, and CD8+ T lymphocytes have been implicated in a number of studies, but a detailed profile of disease-phenotype specific inflammation has yet to emerge. The heterogeneity of the disease has hindered data interpretation while extrapolation of the results of relatively non-invasive studies to the actual pathology found in the distal lung is difficult. Moreover, prominent studies have had frequently conflicting results. Further investigations are needed to marry the different clinical phenotypes of COPD to their respective inflammatory profiles in the airways and thus improve our understanding of the pathogenesis of the disease as a whole.

See end of article for authors' affiliations

Correspondence to Dr R O'Donnell Respiratory Cell and Molecular Biology, Division of Infection, Inflammation and Repair, University of Southampton, Southampton General Hospital, Southampton SOI6 6YD, UK;

raodonnell@eircom.net

Received 12 March 2004 Accepted

22 November 2005
A sthma has been the dominant focus of airways research interest, at least until recent times. A multitude of studies have examined its tapestry of airway inflammation and remodelling. Sophisticated theories have resulted, encompassing environmental exposures, epithelial repair, and epithelial-mesenchymal signalling. ${ }^{1}$ Therapeutic successes have followed, encouraging more interest and further investment. Chronic obstructive airways disease (COPD), on the other hand, has suffered from the unflattering contrast. COPD is generally considered a selfinflicted condition that results, in the majority, from years of smoking and the only effective treatment to date is long term oxygen therapy. Its profile of airways inflammation is, in retrospect, unsurprising. Neutrophils, macrophages, and CD8+ T lymphocytes are, after all, predictable responders to a sustained noxious insult. However, in recent years something of a renaissance has occurred. COPD inflammation research has burgeoned, new treatments are being tested, ${ }^{2}$ and interests are focused now not so much on the cell types but more on the "whys and wherefores" of their actions in COPD.

Historically, the link between airways inflammation and lung pathology in smokers had long been suspected. In the 1950s a post-mortem study of centrilobular emphysema revealed "bronchiolitis" of the airways leading into emphysematous parenchyma. ${ }^{3}$ Further studies confirmed not only that peripheral airways inflammation is associated with remodelling and destruction, ${ }^{4-8}$ but also that its severity increases in parallel with emphysema severity.${ }^{8-10}$ They also revealed that bronchiolar inflammation and emphysema share the same anatomical distribution, ${ }^{11}$ that small airways disease temporally precedes emphysema, ${ }^{4}$ and that bronchiolar inflammation severity correlates with functional impairment. ${ }^{5812}$ It was therefore hypothesised that centrilobular emphysema results from an inflammatory reaction that spreads centrifugally from the bronchioles to involve the parenchyma.'

Animal model studies and in vitro experiments have explored the roles of specific inflammatory cells in COPD, while bronchoscopy, sputum induction and lung resection studies have described airways inflammation in vivo. All have helped to confirm dominant positions in the inflammatory hierarchy for neutrophils, ${ }^{13-15}$ macrophages, ${ }^{16-18}$ and CD8+ $\mathrm{T}$ lymphocytes. ${ }^{19-21}$ Other inflammatory cells such as mast cells, ${ }^{16}$ eosinophils, ${ }^{22}$ and natural killer cells ${ }^{16}$ have been credited with less importance.

\section{KEY INFLAMMATORY CELLS IN COPD Neutrophils}

Neutrophils are front line defensive cells of the immune system and a source of reactive oxygen metabolites, inflammatory cytokines, lipid mediators, antibacterial peptides, and tissue damaging enzymes. ${ }^{23-25}$ They are strongly implicated in both the generation of mucous metaplasia in chronic bronchitis and the destruction of lung tissue in emphysema.

Neutrophil products induce mucus hypersecretion by both an acute secretagogue effect and by augmentation of the bronchial mucus producing apparatus. ${ }^{26} 27$ Mucin gene expression has been proposed as the principal factor governing the differentiation of epithelial cells into goblet cells. $^{28}$ Neutrophil elastase (NE) and reactive oxygen species independently increase epithelial mucin mRNA and protein expression in vitro, ${ }^{29-31}$ possibly via ligand independent transactivation of the cell surface epidermal growth factor receptor (EGFR). ${ }^{29}$ In asthma the epithelial mucin, MUC5AC, and the EGFR are co-localised in airway epithelial goblet cells. ${ }^{32}$ As severe asthma is associated with both massively increased mucus production and neutrophilic airway inflammation, ${ }^{33-36}$ it has been hypothesised that neutrophil driven goblet cell metaplasia is a component of asthma airways remodelling. In COPD, MUC5AC is the principal secreted mucin of the epithelium ${ }^{37}$ and, like

Abbreviations: BAL, bronchoalveolar lavage; $C O P D$, chronic obstructive pulmonary disease; ECP, eosinophilic cationic protein; EGFR, epidermal growth factor receptor; $\mathrm{FEV}_{1}$, forced expiratory volume in 1 second; IFN- $\gamma$, interferon $\gamma$; IL, interleukin; LTB4, leukotriene B4; MMP, matrix metalloproteinase; MPO, myeloperoxidase; NE, neutrophil elastase; NK, natural killer; TNF- $\alpha$, tumour necrosis factor $\alpha$ 


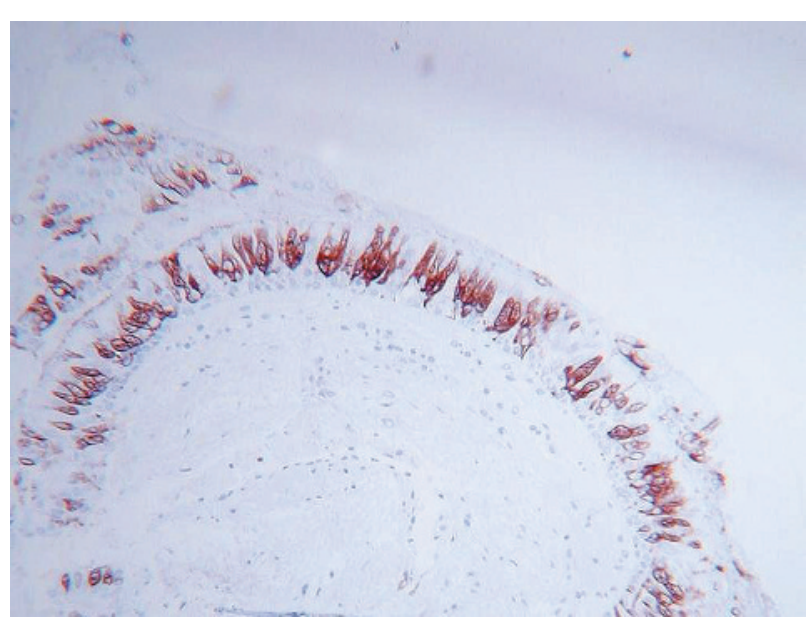

Figure 1 MUC5AC expression in the bronchial epithelium of a smoker with COPD. The photomicrograph shows immunohistochemical MUC5AC staining using an anti-MUC5AC antibody in a GMA embedded bronchial biopsy specimen.

severe asthma and other hypersecretive diseases such as bronchiectasis and cystic fibrosis, neutrophilic airways inflammation is a key disease feature. ${ }^{1333} 343839$ Figure 1 demonstrates epithelial MUC5AC immunochemical staining in a bronchial biopsy specimen taken from a smoker with COPD, indicating its clear expression.

The neutrophil's standing as a potential key cell in emphysema has been assured since inherited $\alpha_{1}$-antitrypsin deficiency was first linked with the disease. The theory emerged that the neutrophil was the perpetrator of a protease/antiprotease imbalance in the lung. ${ }^{25}$ To support this, animal model studies have shown that administration of purified NE produces emphysema, ${ }^{40}$ while deficiency of endogenous NE affords protection against emphysema following exposure to cigarette smoke. ${ }^{41}$ Human studies have demonstrated NE in emphysematous tissue, ${ }^{42}$ increased products of elastase activity in urine and plasma from patients with $\mathrm{COPD}^{43}$ and a correlation between emphysema severity and elastase levels in peripheral blood neutrophils. ${ }^{44}$ In vitro, peripheral blood neutrophils from subjects with

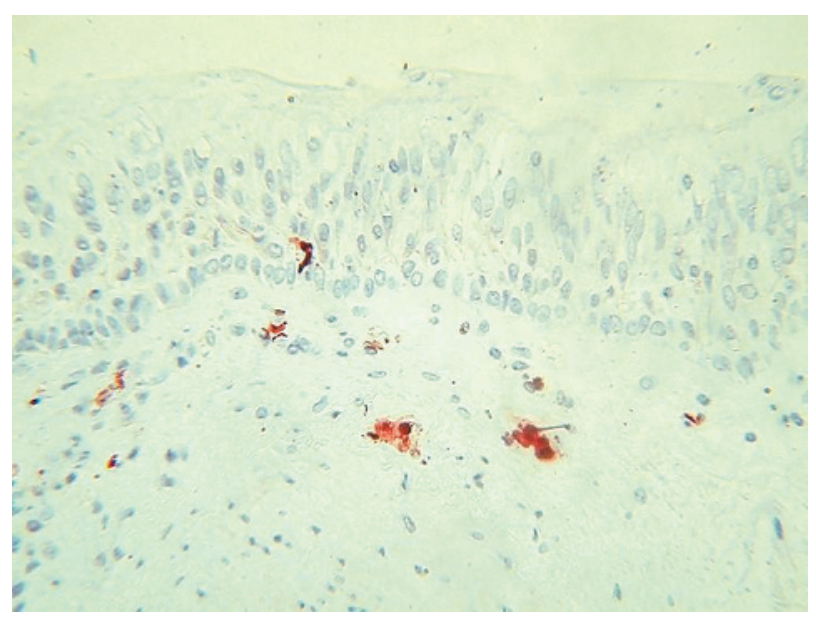

Figure 2 Neutrophils infiltrating bronchial submucosa and epithelium in a smoker with COPD. The photomicrograph shows immunohistochemical cytoplasmic staining using an antimyeloperoxidase antibody in a GMA embedded bronchial biopsy specimen. emphysema digest more extracellular connective tissue protein than those taken from controls. ${ }^{45}$

The in vivo evidence linking neutrophils with COPD is abundant. Analyses of induced sputum ${ }^{14}{ }^{15} 46$ and airway lavage fluid 224748 consistently demonstrate increased neutrophil counts and neutrophil derived enzyme levels in COPD, both when stable and during exacerbations. ${ }^{46}{ }^{49-53}$ Within the airway wall, however, confirmation of neutrophilic airway inflammation has proved more elusive. Some investigations showing airway wall neutrophilia ${ }^{16}{ }^{18}{ }^{4}$ are countered by others that do not, ${ }_{17} 1922$ an inconsistency that may reflect the short tissue lifespan of the infiltrating neutrophil. More recent studies have diversified their focus in an attempt to "capture" the elusive neutrophil. Bronchial biopsy specimens taken during a COPD exacerbation revealed higher neutrophil counts than those taken in stable disease. ${ }^{55}$ Analyses of airway smooth muscle have shown a relationship between neutrophil infiltration and both computed tomographic measurements of air trapping ${ }^{56}$ and severity of airflow obstruction. ${ }^{57}$ The investigators speculated that exposure to inflammatory mediators could affect the structure and contractility of airway smooth muscle, contributing to peripheral airways obstruction. This complements reports of a strong relationship between peripheral airways dysfunction in COPD and sputum neutrophil counts. ${ }^{58}$ Figure 2 shows immunochemically stained neutrophils infiltrating the bronchial submucosa and epithelium in a bronchial biopsy specimen, consistent with this hypothesis.

\section{Macrophages}

Macrophages account for the majority of inflammatory cells recovered by airway lavage, regardless of whether or not the subjects are non-smokers, healthy smokers or smokers with airways disease. ${ }^{48} 59$ Compounds released by macrophages include reactive oxygen species, chemotactic factors, inflammatory cytokines, smooth muscle constrictors, mucus gland activators, and extracellular matrix proteins. Also included is an array of matrix metalloprotease enzymes (MMPs). These can, when combined, degrade a similar spectrum of proteins to neutrophil enzymes ${ }^{25}$ and they are also believed to facilitate leucocyte migration and infiltration into injured tissues. ${ }^{60}$ Although macrophages do not transcribe the NE gene, their ability to internalise the enzyme has led to the proposal that macrophage released NE can add further to the proteolytic potential of the cell. ${ }^{61}$

Although macrophages have the theoretical potential to induce mucus hypersecretion via products with secretagogue activity such as leukotriene B4 (LTB4) and interleukin 1 (IL1), most studies have focused on their possible role in emphysema, particularly via MMP production. In animal models administration of aerosolised alveolar macrophages produces emphysema, ${ }^{40}$ as does overexpression of MMP- $1 .{ }^{62}$ Use of a broad spectrum MMP inhibitor attenuates both the initial inflammatory response and the severity of emphysema in guinea pigs exposed to cigarette smoke..$^{63}$ In vitro, cultured alveolar macrophages taken from subjects with COPD express increased amounts of both MMP-1 and MMP- $9^{61}$ while, in vivo, immunoreactivity for MMP-2 and MMP -9 is demonstrably increased in COPD. ${ }^{64}$

MMP-12, in particular, has been a focus of increasing attention in emphysema. In mice, deficiency of MMP-12 appears to be protective against cigarette smoke induced lung destruction. ${ }^{65}$ In vivo, airway and alveolar macrophage MMP12 expression in COPD subjects is enhanced compared with healthy controls ${ }^{66}{ }^{67}$ Recent evidence, moreover, suggests that the role of MMP-12 may go beyond matrix degradation. In mouse models its presence is required for cigarette smoke induced neutrophil influx into the lung, ${ }^{68}{ }^{69}$ possibly via release of the pro-inflammatory cytokine tumour necrosis 


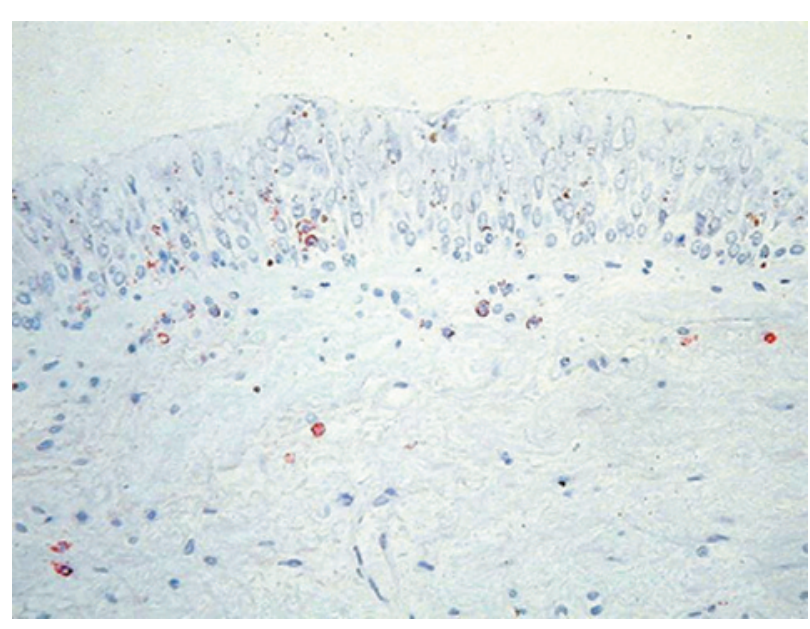

Figure $3 \mathrm{CD} 8+$ cells infiltrating both submucosa and epithelium in a smoker with COPD. The photomicrograph shows immunohistochemical membrane staining using an anti-CD8 antibody in a GMA embedded bronchial biopsy specimen.

factor $\alpha($ TNF- $\alpha)$ with subsequent upregulation of vascular adhesion molecule VCAM- $1 .^{70}$ This supports the view that neutrophils and macrophages are co-dependent on one another to produce an elastolytic inflammatory response in airways exposed to cigarette smoke. ${ }^{70}$

Studies of emphysematous lung tissue from human subjects have shown a direct relationship between alveolar macrophage density in the parenchyma and the severity of lung destruction. ${ }^{71}$ Moreover, numerous investigations have found macrophage numbers to be increased in the bronchial submucosa, ${ }^{14} 16171972$ bronchial glands, ${ }^{18}$ and small airways epithelium $^{73}$ of subjects with COPD. Macrophage counts in induced sputum or bronchoalveolar lavage (BAL) fluid in COPD vary depending on whether relative or absolute cell counts are used. Relative macrophage counts are often reduced, ${ }^{14} 1574$ a reflection, most likely, of increased neutrophil percentages. Absolute counts, on the other hand, are increased both in sputum ${ }^{46}$ and BAL fluid. ${ }^{48} 5975$

\section{T lymphocytes}

In asthma the CD4+ T cell is the proposed orchestrator of a Th2 type immune response in the airways. ${ }^{76}$ In COPD the CD8+ cell is the accepted crucial lymphocyte subtype. An increase in total $\mathrm{T}$ cells (CD3+ cells), which includes both CD4+ and CD8+ cells, occurs in the alveolar walls in emphysema $^{1021}$ but CD8+ cells are predominant. ${ }^{21}$ Increased CD8+ cell numbers are also found in both the large ${ }^{19}$ and small ${ }^{20}{ }^{73}$ airway walls in COPD and in peripheral airway smooth muscle. ${ }^{57}$ Figure 3 shows CD8+ cells infiltrating the bronchial submucosa and epithelium in a bronchial biopsy specimen.

Speculation has surrounded the role of CD8+ cells in emphysema. A key function of the CD8+ cell is to combat viruses either by cytolysis of infected cells or induction of apoptosis. ${ }^{77}$ Collateral tissue damage is a possible consequence; in respiratory syncytial virus (RSV) infected mice, for example, excessive CD8+ cell activation results in potentially lethal pulmonary damage. ${ }^{79}$ In smokers infected with human immunodeficiency virus (HIV), high CD8+ cell numbers in BAL fluid have been associated with an accelerated onset of emphysema. ${ }^{80}$

If CD8+ cells destroy lung parenchyma, the mechanism is uncertain. They have, in theory, the potential to damage the lung interstitium directly via release of lytic substances such as perforin and granzyme. ${ }^{81}$ It was observed recently that CD8+ cells recovered from the sputum of COPD patients display higher levels of perforin expression and increased cytotoxic activity than CD8+ cells taken from control subjects. ${ }^{82}$ Another possibility is that CD8+ cells induce structural cell apoptosis. ${ }^{21}$ Alveolar cell turnover does appear to increase in emphysema as increased numbers of alveolar epithelial and endothelial cells undergo both proliferation and apoptosis. ${ }^{83-85}$ Moreover, an association has been observed between apoptosing cell numbers and CD8+ T cell numbers in the alveolar walls. ${ }^{21}$ The possibility remains, however, that such associations are a secondary phenomenon. Given their potential suppressor function, the infiltrating CD8+ cells may actually serve to inhibit the inflammatory process. Further studies are needed to define the activity of infiltrating CD8+ cells in emphysema.

Prior activation of $\mathrm{T}$ cells by antigen presentation is generally required before they can infiltrate non-lymphoid tissue such as the lung. Although the nature of the proposed antigen in COPD is unknown, two hypotheses have been put forward. Enelow and colleagues demonstrated that recognition of a lung "autoantigen" by T cells can produce lung injury in the absence of a viral stimulus, and this damage was mediated or amplified by non-antigen specific inflammatory cells such as macrophages. ${ }^{86}$ It was therefore hypothesised that repetitive injury to the lung, as a result of chronic smoking and inflammation, results in structural alteration of self-antigens allowing them to be recognised by $\mathrm{T}$ cells. ${ }^{21}$ Alternatively, a persistent intracellular pathogen may provide a foreign antigenic stimulus. One such candidate is adenovirus, as suggested by Retamales and colleagues ${ }^{87}$ who found a 41 -fold increase in alveolar epithelial cells expressing the adenoviral transactivating protein ElA in subjects with severe emphysema compared with healthy smokers.

A number of molecules have been proposed to mediate pulmonary $\mathrm{T}$ cell infiltration in COPD. RANTES (regulated upon activation, normal $\mathrm{T}$ cell expressed and secreted), a potent chemoattractant that is overexpressed in exacerbations of chronic bronchitis, ${ }^{88}$ is believed to act synergistically with CD8+ cytolytic cells to enhance apoptosis of virally infected cells. ${ }^{89} 90$ It was therefore postulated that, when CD8+ cells predominate, recurrent viral infections with resulting increased RANTES levels may promote CD8+ cell mediated tissue damage. ${ }^{88}$ Thl type cycle of inflammation has also been suggested; in COPD airways infiltrating CD8+ cells express more of the chemokine receptor CXCR3, its ligand CXCL10, and the inflammatory cytokine interferon $\gamma$ $($ IFN- $\gamma$ ). This has led to the suggestion that an inflammatory insult induces increased airway expression of CXCL10 and IFN- $\gamma$, that this recruits CXCR3 bearing CD8+ cells, and that these-via expression of IFN- $\gamma$-could induce further CXCL10 expression thus perpetuating a cycle of CD8+ inflammation. ${ }^{91}$

The function of CD4+ cells in COPD is unknown. CD4+ cells, in addition to CD8+ cells, are increased in the small airway walls of smokers with severe COPD ${ }^{73}$ They have the potential to contribute to the inflammatory process via production of a variety of pro-inflammatory cytokines including TNF- $\alpha$ and granulocyte-macrophage colony-stimulating factor (GM-CSF), the Thl agents IFN- $\gamma$ and IL-2, and the Th2 agents IL-4, IL-5, and IL-6. It has also been hypothesised that their actions as $\mathrm{T}$ helper cells, priming CD8+ cytotoxic responses, maintaining their memory and ensuring their survival, may be as important to the development of emphysema as the CD8+ cells themselves. ${ }^{21}$

\section{Natural killer (NK) T lymphocytes}

NK cells are a distinct population of specialised cytotoxic lymphocytes that target transformed or virus infected cells. $^{92}{ }^{93}$ Although the function of NK cells in COPD has not been widely studied, one investigation suggested that 
they are found in increased numbers in the large airway submucosa of smokers with COPD, with the hypothesis that excessive NK cell recruitment in COPD occurs due to repeated viral or bacterial infections. ${ }^{16}$ However, a study measuring lymphocyte subpopulations in the alveolar walls of nonsmokers, healthy smokers, and smokers with emphysema found no increase in NK cell numbers in subjects with emphysema. ${ }^{21}$

\section{Eosinophils and mast cells}

Although eosinophils and mast cells are important effector cells in asthma, neither has been ascribed a prominent role in COPD. In exacerbations of COPD airway wall eosinophilia has been observed at a level similar to that found in asthma, ${ }^{88} 94$ with an associated increase in RANTES expression by airway subepithelial and epithelial cells. ${ }^{88}$ In stable COPD, increased eosinophil counts have been found in sputum $^{74}$ BAL fluid, ${ }^{48}$ and in the airway wall. ${ }^{22} 5495$ Increased levels of eosinophilic cationic protein (ECP) in BAL fluid ${ }^{96}$ and induced sputum $^{469798}$ have also been observed. However, some studies have failed to confirm that any airway eosinophilia occurs in COPD, ${ }^{15} 17-192299$ while others have suggested that the eosinophils, even if they are present, are not activated. ${ }^{1422}$ The mechanism underlying eosinophilic infiltration seems to differ from asthma in that the key chemokines IL-4, IL-5 and eotaxin do not appear to be overexpressed in COPD airways. ${ }^{54}$ It has been hypothesised that any influx of these cells is merely a by-product of smoking induced inflammation. A possible mediator is the chemokine IL-8. Although normally associated with neutrophil chemotaxis, IL-8 exerts a chemotactic effect on primed eosinophils $^{100}{ }^{101}$ and correlates with BAL fluid levels of ECP in chronic bronchitis. ${ }^{52}$

Some reports have shown that increased numbers of eosinophils in sputum ${ }^{74} 102103$ and BAL fluid ${ }^{104}$ taken from COPD subjects are predictive of a clinical response to steroid treatment. These results might suggest that eosinophils play a role in a clinical subset of COPD that has inflammatory features in common with that of asthma. However, the two diseases remain, in general, phenotypically dissimilar as even subjects with asthma who have fixed airflow obstruction have significantly higher percentages of eosinophils and lower percentages of neutrophils in both sputum and BAL fluid than COPD patients with similar disease severity. ${ }^{105}$

The ability of mast cells to release an array of mediators has invited speculation regarding their possible role in COPD inflammation. This could include neutrophil recruitment via the release of chemotactic factors, tissue injury by the actions of the secreted enzymes tryptase, chymase and elastase, and mucus hypersecretion via the potent secretagogue action of mast cell chymase. ${ }^{106}$ Some studies of COPD airways have revealed increased mast cell numbers in the airway wall. ${ }^{107} 108$ In addition, one study which found that mast cell degranulation in the bronchial gland layer appeared more marked in subjects with chronic bronchitis than in healthy controls suggested that increased mast cell activity may also be present. ${ }^{108}$ These findings are countered, however, by reports displaying no evidence of mast cell abundance in either the airways or parenchyma in COPD subjects. ${ }^{16-18} 739499$

\section{OBSTACLES TO RESEARCH INTO COPD INFLAMMATION}

A detailed profile of disease phenotype specific inflammation has yet to emerge in COPD. There are many reasons for this, but chief among them may be the very nature of the condition itself. COPD is a heterogeneous disease, so the pathological significance of inflammatory cell measurements is often difficult to divine. The clinical severity varies considerably, asymptomatic disease is common, ${ }^{109} 110$ and interobserver variability exists in the detection of physical signs allowing mild cases to go undetected. ${ }^{111} 112$ Moreover, none of the common clinical tests give a complete picture of the disease. Spirometric tests are inadequate for the detection of early COPD, ${ }^{113} 114$ airflow obstruction severity is a poor predictor of symptom severity, ${ }^{115}$ and impairment of carbon monoxide gas transfer is not specific to emphysema and may occur by separate mechanisms in smokers. ${ }^{116-119}$

Linkage of lung function readings to the underlying pathology is hampered by the fact that both peripheral airway remodelling ${ }^{120121}$ and emphysema ${ }^{6122}$ result in airflow obstruction while emphysema is commonly found in smokers who have not developed airflow obstruction at all. ${ }^{13} 114$ Thus, characterisation of research subjects based only on clinical impression and lung function-as was the case with many studies ${ }^{14} 2095$-fails to provide a clear insight into the underlying pathology. Neutrophil studies provide a prime example of the importance of distinguishing COPD phenotypes. Sputum neutrophil counts correlate with the severity of airflow obstruction in COPD, ${ }^{15}{ }^{19}$ and smokers with severe emphysema have neutrophilic inflammation in the alveolar walls and air spaces. ${ }^{87}$ However, in mild emphysema there is neither $\mathrm{BAL}^{49}$ nor alveolar neutrophilia, ${ }^{87}$ even though BAL fluid levels of neutrophil degranulation products and the neutrophil chemokine IL-8 are increased. ${ }^{49}{ }^{123}$ Mild emphysema would often go undetected on lung function testing so, without the use of CT scanning, such patients would be classified as healthy smokers.

A further obstacle is that the most practical investigative techniques have natural limitations. The predominant pathology is found in the not easily accessible peripheral airways and lung parenchyma. To what extent proximal airway biopsies represent events in the distal lung is uncertain. Although BAL and induced sputum sample more distally, the correlation between luminal and tissue inflammation is also unknown. Moreover, the results depend on the protocol in use. Inflammatory cell numbers vary depending on the lung region sampled, with neutrophils more numerous in the proximal bronchial tree and macrophages predominant more distally. Digital subtraction angiography has shown that BLF (fluid aspirated back from the initially instilled aliquots) samples proximal airways, whereas successive aliquots (BAL fluid) may reflect distal airway and alveolar events. ${ }^{124}$ Thus, in healthy smokers neutrophil percentages decline in successive BAL fluid aliquots. ${ }^{125}$ Sputum induction, similarly, is prone to sampling effects. In subjects with COPD, induced sputum contains higher percentages of neutrophils and lower percentages of macrophages than BAL fluid, most probably because the more proximal airways are sampled. ${ }^{14} 126$ However, increasing the duration of the induction results in a progressive reversal of these proportions, possibly due to increasingly peripheral airways sampling. ${ }^{127}$ Standardisation of induction duration is therefore important if reliable comparisons are to be made between different centres.

Prominent studies of airway inflammation in COPD have had conflicting results. Some investigations which showed CD8+ T lymphocyte infiltration of the airways ${ }^{19} 20$ have not been confirmed by others. ${ }^{14}{ }^{16}$ Macrophage infiltration has similarly been both confirmed ${ }^{1759}$ and refuted, ${ }^{20} 95$ while studies measuring neutrophils, eosinophils, and mast cells in airway wall and sputum have also produced inconsistent results.

The potentially crucial impact of infection and exacerbations on airways inflammation and disease severity remains unquantified. Frequent exacerbations of COPD are associated with a faster decline in forced expiratory volume in 1 second $\left(\mathrm{FEV}_{1}\right)$ over time. ${ }^{128}$ Exacerbations are also associated with raised sputum counts of lymphocytes, neutrophils, and 
eosinophils. ${ }^{129}$ In the airway wall, similarly, both neutrophilia and eosinophilia are observed, as is overexpression of related chemokines IL-8, CXCL5 and RANTES. ${ }^{5588} 94$ Bacterial infections, specifically, have been linked to increases in both neutrophil activation markers and associated inflammatory mediators including myeloperoxidase (MPO), NE, LTB4 and IL-8. ${ }^{130}{ }^{131}$ Even in the absence of acute infection, airway bacterial colonisation is well recognised in COPD. ${ }^{132}$ Such colonisation has been correlated with airway neutrophil activation, ${ }^{133}$ sputum levels of the pro-inflammatory cytokines IL-8, LTB4 and TNF- $\alpha,{ }^{134}{ }^{135}$ airflow obstruction severity, ${ }^{136}$ and a more rapid decline in $\mathrm{FEV}_{1}$ over time in smokers. ${ }^{137}$ It has been hypothesised that chronic lower airway bacterial colonisation may accelerate the development of airflow limitation via both increased airway inflammation in stable disease and by predisposing to more frequent exacerbations. ${ }^{133} 137138$ Although most studies relating inflammation to clinical disease severity have excluded acute infection from their subjects on clinical grounds, airway colonisation has not been ruled out to the same extent.

The effects of current smoking remain uncertain. Most investigators have preferred to record the pack year history instead. Rennard and colleagues showed that short term smoking reduction is associated with a reduction in airway inflammation in heavy smokers. ${ }^{139}$ Willemse and colleagues found a positive association between current smoking and macrophage numbers in both sputum and bronchial biopsy specimens. ${ }^{140}$ Other investigators have shown, however, that current and ex-smokers with COPD have similar degrees of inflammation in bronchial biopsy ${ }^{141}$ and induced sputum ${ }^{142}$ samples. Thus, although intuitively one would expect the ongoing insult to the airways to be relevant, the jury remains out as to whether differences in current smoking contribute to the variability of results between different studies.

Thus, to date, diverse methods and, often, diverse results, have contributed to uncertainty surrounding the inflammatory profile of COPD. If future anti-inflammatory strategies are to be tested, then measurements of inflammation before and after treatment in bronchoscopic or sputum samples may be necessary. More clarity is needed as to the strength of the relationships between proximal airway inflammation, distal airway inflammation, and lung pathology.

\section{CONCLUSION}

That airway inflammation is central to the pathogenesis of COPD appears beyond doubt. However, studies to date have varied widely in terms of the depth of disease characterisation, their allowance for confounding factors such as current smoking and infection, and the investigative methodologies employed. Future studies need to clarify the relationship between each specific inflammatory cell type and each of the remodelling and destructive processes found in COPD airways. Further research combining well validated techniques-specifically, comparison of preoperative endobronchial biopsy samples with examination of resected lung specimens and careful patient phenotyping-may help.

\section{Authors' affiliations \\ R O'Donnell, D Breen, S Wilson, R Djukanovic, Respiratory Cell and Molecular Biology, Division of Infection, Inflammation and Repair, University of Southampton, Southampton General Hospital, Southampton SO16 6YD, UK \\ Funding: none. \\ Competing interests: none.}

\section{REFERENCES}

1 Holgate ST, Davies DE, Lackie PM, et al. Epithelial-mesenchymal interactions in the pathogenesis of asthma. J Allergy Clin Immunol 2000;105:193-204.
2 van der Vaart H, Koeter GH, Postma DS, et al. First study of infliximab treatment in patients with chronic obstructive pulmonary disease. Am J Respir Crit Care Med 2005; 172:465-9.

3 Leopold JG, Gough J. The centrilobular form of hypertrophic emphysema and its relation to chronic bronchitis. Thorax 1957;12:219-35.

4 Cosio M, Ghezzo H, Hogg JC, et al. The relations between structural changes in small airways and pulmonary function tests. N Engl J Med 1978;298:1277-81.

5 Wright JL, Lawson LM, Pare PD, et al. The detection of small airways disease. Am Rev Respir Dis 1984; 129:989-94.

6 Nagai A, West WW, Thurlbeck WM. The National Institutes of Health Intermittent Positive-Pressure Breathing trial: pathology studies. II. Correlation between morphologic findings, clinical findings, and evidence of expiratory air-flow obstruction. Am Rev Respir Dis 1985;132:946-53.

7 Mitchell RS, Stanford RE, Johnson JM, et al. The morphologic features of the bronchi, bronchioles, and alveoli in chronic airway obstruction: a clinicopathologic study. Am Rev Respir Dis 1976;1 14:137-45.

8 Cosio MG, Hale KA, Niewoehner DE. Morphologic and morphometric effects of prolonged cigarette smoking on the small airways. Am Rev Respir Dis 1980;122:265-21.

9 Saetta M, Finkelstein R, Cosio MG. Morphological and cellular basis for airflow limitation in smokers. Eur Respir J 1994;7:1505-15.

10 Finkelstein R, Ma HD, Ghezzo H, et al. Morphometry of small airways in smokers and its relationship to emphysema type and hyperresponsiveness. Am J Respir Crit Care Med 1995;152:267-76.

11 Remy-Jardin M, Remy J, Gosselin B, et al. Lung parenchymal changes secondary to cigarette smoking: pathologic-CT correlations. Radiology 1993; 186:643-51.

12 Morrison NJ, Abboud RT, Ramadan F, et al. Comparison of single breath carbon monoxide diffusing capacity and pressure-volume curves in detecting emphysema. Am Rev Respir Dis 1989;139:1179-87.

13 Keatings VM, Collins PD, Scott DM, et al. Differences in interleukin-8 and tumor necrosis factor-alpha in induced sputum from patients with chronic obstructive pulmonary disease or asthma. Am J Respir Crit Care Med 1996; 153:530-4.

14 Rutgers SR, Postma DS, ten Hacken NH, et al. Ongoing airway inflammation in patients with COPD who do not currently smoke. Thorax 2000;55:12-8.

15 Peleman RA, Rytila PH, Kips JC, et al. The cellular composition of induced sputum in chronic obstructive pulmonary disease. Eur Respir $J$ 1999; 13:839-43.

16 Di Stefano A, Capelli A, Lusuardi M, et al. Severity of airflow limitation is associated with severity of airway inflammation in smokers. Am J Respir Crit Care Med 1998; 158:1277-85.

17 Saetta M, Di Stefano A, Maestrelli P, et al. Activated T-lymphocytes and macrophages in bronchial mucosa of subjects with chronic bronchitis. Am Rev Respir Dis 1993;147:301-6.

18 Saetta M, Turato G, Facchini FM, et al. Inflammatory cells in the bronchial glands of smokers with chronic bronchitis. Am J Respir Crit Care Med 1997; 156:1633-9.

19 O'Shaughnessy TC, Ansari TW, Barnes NC, et al. Inflammation in bronchial biopsies of subjects with chronic bronchitis: inverse relationship of CD8+ T lymphocytes with FEV1. Am J Respir Crit Care Med 1997; 155:852-7.

20 Saetta M, Di Stefano A, Turato G, et al. CD8+ T-lymphocytes in peripheral airways of smokers with chronic obstructive pulmonary disease. Am J Respir Crit Care Med 1998;157:822-6.

21 Majo J, Ghezzo H, Cosio MG. Lymphocyte population and apoptosis in the lungs of smokers and their relation to emphysema. Eur Respir J 2001; 17:946-53.

22 Lacoste JY, Bousquet J, Chanez P, et al. Eosinophilic and neutrophilic inflammation in asthma, chronic bronchitis, and chronic obstructive pulmonary disease. J Allergy Clin Immunol 1993;92:537-48.

23 Hiemstra PS, van Wetering S, Stolk J. Neutrophil serine proteinases and defensins in chronic obstructive pulmonary disease: effects on pulmonary epithelium. Eur Respir J 1998;12:1200-8.

24 Dubravec DB, Spriggs DR, Mannick JA, et al. Circulating human peripheral blood granulocytes synthesize and secrete tumor necrosis factor alpha. Proc Natl Acad Sci USA 1990;87:6758-61.

25 Tetley TD. New perspectives on basic mechanisms in lung disease. 6. Proteinase imbalance: its role in lung disease. Thorax 1993;48:560-5.

26 Brever R, Christensen TG, Lucey EC, et al. An ultrastructural morphometric analysis of elastase-treated hamster bronchi shows discharge followed by progressive accumulation of secretory granules. Am Rev Respir Dis 1987; 136:698-703.

27 Nadel JA. Role of mast cell and neutrophil proteases in airway secretion. Am Rev Respir Dis 1991;144:S48-51.

28 Rogers DF. Airway goblet cells: responsive and adaptable front-line defenders. Eur Respir J 1994;7:1690-706.

29 Takeyama K, Dabbagh K, Jeong Shim J, et al. Oxidative stress causes mucin synthesis via transactivation of epidermal growth factor receptor: role of neutrophils. J Immunol 2000; 164:1546-52.

30 Voynow JA, Young LR, Wang Y, et al. Neutrophil elastase increases MUC5AC mRNA and protein expression in respiratory epithelial cells. Am J Physiol 1999;276:L835-43.

31 Fischer B, Voynow J. Neutrophil elastase induces MUC5AC messenger RNA expression by an oxidant-dependent mechanism. Chest 2000;117/5 Suppl 1):317-20S.

32 Takeyama K, Fahy JV, Nadel JA. Relationship of epidermal growth factor receptors to goblet cell production in human bronchi. Am J Respir Crit Care Med 2001; 163:511-6. 
33 Sur S, Crotty TB, Kephart GM, et al. Sudden-onset fatal asthma. A distinc entity with few eosinophils and relatively more neutrophils in the airway submucosa? Am Rev Respir Dis 1993;148:713-9.

34 Fahy JV, Kim KW, Liu J, et al. Prominent neutrophilic inflammation in sputum from subjects with asthma exacerbation. J Allergy Clin Immunol 1995;95:843-52.

35 Wenzel SE, Szefler SJ, Leung DY, et al. Bronchoscopic evaluation of severe asthma. Persistent inflammation associated with high dose glucocorticoids. Am J Respir Crit Care Med 1997;156:737-43.

36 Wenzel SE, Schwartz LB, Langmack EL, et al. Evidence that severe asthma can be divided pathologically into two inflammatory subtypes with distinct physiologic and clinical characteristics. Am J Respir Crit Care Med 1999;160:1001-8.

37 O'Donnell RA, Richter A, Ward J, et al. Expression of ErbB receptors and mucins in the airways of long term current smokers. Thorax 2004:59:1032-40.

38 Fahy JV, Schuster A, Ueki I, et al. Mucus hypersecretion in bronchiectasis. The role of neutrophil proteases. Am Rev Respir Dis 1992;146:1430-3.

39 Khan TZ, Wagener JS, Bost T, et al. Early pulmonary inflammation in infants with cystic fibrosis. Am J Respir Crit Care Med 1995;151:1075-82.

40 Snider GL, Lucey EC, Stone PJ. Animal models of emphysema. Am Rev Respir Dis 1986;133:149-69

41 Shapiro SD, Goldstein NM, Houghton AM, et al. Neutrophil elastase contributes to cigarette smoke-induced emphysema in mice. Am J Pathol 2003; 163:2329-35

42 Damiano VV, Tsang A, Kucich $U$, et al. Immunolocalization of elastase in human emphysematous lungs. J Clin Invest 1986;78:482-93.

43 Gottlieb DJ, Stone PJ, Sparrow D, et al. Urinary desmosine excretion in smokers with and without rapid decline of lung function: the Normative Aging Study. Am J Respir Crit Care Med 1996;154:1290-5.

44 Galdston M, Melnick EL, Goldring RM, et al. Interactions of neutrophil elastase, serum trypsin inhibitory activity, and smoking history as risk factors for chronic obstructive pulmonary disease in patients with $M M, M Z$, and $Z Z$ phenotypes for alpha-1 antitrypsin. Am Rev Respir Dis 1977;1 16:837-46.

45 Burnett D, Chamba A, Hill SL, et al. Neutrophils from subjects with chronic obstructive lung disease show enhanced chemotaxis and extracellular proteolysis. Lancet 1987;2:1043-6.

46 Keatings VM, Jatakanon A, Worsdell YM, et al. Effects of inhaled and oral glucocorticoids on inflammatory indices in asthma and COPD. Am J Respir Crit Care Med 1997; 155:542-8.

47 Thompson AB, Daughton D, Robbins RA, et al. Intraluminal airway inflammation in chronic bronchitis. Characterization and correlation with clinical parameters. Am Rev Respir Dis 1989;140:1527-37.

48 Linden $M$, Rasmussen JB, Piitulainen E, et al. Airway inflammation in smokers with nonobstructive and obstructive chronic bronchitis. Am Rev Respir Dis 1993; 148: 1226-32

49 Betsuyaku T, Nishimura M, Takeyabu K, et al. Neutrophil granule proteins in bronchoalveolar lavage fluid from subjects with subclinical emphysema. Am J Respir Crit Care Med 1999;159:1985-91.

50 Drost EM, Skwarski KM, Sauleda J, et al. Oxidative stress and airway inflammation in severe exacerbations of COPD. Thorax 2005;60:293-300.

51 Hill AT, Bayley D, Stockley RA. The interrelationship of sputum inflammatory markers in patients with chronic bronchitis. Am J Respir Crit Care Med 1999;160:893-8

52 Riise GC, Ahlstedt S, Larsson S, et al. Bronchial inflammation in chronic bronchitis assessed by measurement of cell products in bronchial lavage fluid. Thorax 1995:50:360-5.

53 Yoshioka A, Betsuyaku T, Nishimura M, et al. Excessive neutrophil elastase in bronchoalveolar lavage fluid in subclinical emphysema. Am J Respir Crit Care Med 1995; 152:2127-32.

54 Panzner P, Lafitte JJ, Tsicopoulos A, et al. Marked up-regulation of T lymphocytes and expression of interleukin-9 in bronchial biopsies from patients with chronic bronchitis with obstruction. Chest 2003; 124:1909-15.

55 Qiu Y, Zhu J, Bandi V, et al. Biopsy neutrophilia, neutrophil chemokine and receptor gene expression in severe exacerbations of chronic obstructive pulmonary disease. Am J Respir Crit Care Med 2003; 168:968-75

56 Berger $P$, Laurent $F$, Begueret $H$, et al. Structure and function of small airways in smokers: relationship between air trapping at CT and airway inflammation. Radiology 2003;228:85-94.

57 Baraldo S, Turato G, Badin C, et al. Neutrophilic infiltration within the airway smooth muscle in patients with COPD. Thorax 2004;59:308-12.

58 O'Donnell RA, Peebles C, Ward JA, et al. Relationship between peripheral airway dysfunction, airway obstruction, and neutrophilic inflammation in COPD. Thorax 2004;59:837-42.

59 Kuschner WG, D'Alessandro A, Wong H, et al. Dose-dependent cigarette smoking-related inflammatory responses in healthy adults. Eur Respir $J$ 1996:9:1989-94.

60 Kumagai K, Ohno I, Okada S, et al. Inhibition of matrix metalloproteinases prevents allergen-induced airway inflammation in a murine model of asthma. J Immunol 1999;162:4212-9.

61 Finlay GA, O'Driscoll LR, Russell KJ, et al. Matrix metalloproteinase expression and production by alveolar macrophages in emphysema. Am J Respir Crit Care Med 1997; 156:240-7.

62 D'Armiento JDS, Okada Y, Berg RA, et al. Collagenase expression in the lungs of transgenic mice causes pulmonary emphysema. Cell 1992;71:955-61.

63 Selman M, Cisneros-Lira J, Gaxiola M, et al. Matrix metalloproteinases inhibition attenuates tobacco smoke-induced emphysema in guinea pigs. Chest 2003;123:1633-41.
64 Segura-Valdez L, Pardo A, Gaxiola M, et al. Upregulation of gelatinases A and $B$, collagenases 1 and 2 , and increased parenchymal cell death in COPD. Chest 2000;117:684-94.

65 Shapiro SD. The macrophage in chronic obstructive pulmonary disease. Am J Respir Crit Care Med 1999; 160:S29-32.

66 Molet SBC, Lena H, Germain N, et al. Increase in macrophage elastase (MMP-12) in lungs from patients with chronic obstructive pulmonary disease. Inflamm Res 2005;54:31-6.

67 Montano M, Beccerril C, Ruiz V, et al. Matrix metalloproteinases activity in COPD associated with wood smoke. Chest 2004;125:466-72

68 Churg A, Zay K, Shay S, et al. Acute cigarette smoke-induced connective tissue breakdown requires both neutrophils and macrophage metalloelastase in mice. Am J Respir Cell Mol Biol 2002;27:368-74.

69 Dhami R, Gilks B, Xie C, et al. Acute cigarette smoke-induced connective tissue breakdown is mediated by neutrophils and prevented by alpha 1antitrypsin. Am J Respir Cell Mol Biol 2000;22:244-52.

70 Churg A, Wang RD, Tai $\mathrm{H}$, et al. Macrophage metalloelastase mediates acute cigarette smoke-induced inflammation via tumor necrosis factor- $\alpha$ release. Am J Respir Crit Care Med 2003;167:1083-9.

71 Finkelstein R, Fraser RS, Ghezzo H, et al. Alveolar inflammation and its relation to emphysema in smokers. Am J Respir Crit Care Med 1995:152:1666-72.

72 Di Stefano A, Turato G, Maestrelli P, et al. Airflow limitation in chronic bronchitis is associated with T- lymphocyte and macrophage infiltration of the bronchial mucosa. Am J Respir Crit Care Med 1996;153:629-32.

73 Turato G, Zuin R, Miniati M, et al. Airway inflammation in severe chronic obstructive pulmonary disease: relationship with lung function and radiologic emphysema. Am J Respir Crit Care Med 2002;166:105-10.

74 Fujimoto K, Kubo K, Yamamoto H, et al. Eosinophilic inflammation in the airway is related to glucocorticoid reversibility in patients with pulmonary emphysema. Chest 1999;115:697-702.

75 Capelli A, Di Stefano A, Gnemmi I, et al. Increased MCP-1 and MIP-1 beta in bronchoalveolar lavage fluid of chronic bronchitics. Eur Respir J $1999 ; 14: 160-5$

76 Holgate ST, Wilson JR, Howarth PH. New insights into airway inflammation by endobronchial biopsy. Am Rev Respir Dis 1992;145:S2-6.

77 Kagi D, Vignaux F, Ledermann B, et al. Fas and perforin pathways as major mechanisms of T cell-mediated cytotoxicity. Science 1994;265:528-30.

78 Lowin B, Hahne M, Mattmann C, et al. Cytolytic T-cell cytotoxicity is mediated through perforin and Fas lytic pathways. Nature 1994;370:650-2.

79 Cannon MJ, Openshaw PJ, Askonas BA. Cytotoxic T cells clear virus but augment lung pathology in mice infected with respiratory syncytial virus. $J$ Exp Med 1988;168:1163-8.

80 Diaz PT, King MA, Pacht ER, et al. Increased susceptibility to pulmonary emphysema among HIV-seropositive smokers. Ann Intern Med 2000;132:369-72.

81 Garcia_Sanz JA, Velotti F, MacDonald HR, et al. Appearance of granuleassociated molecules during activation of cytolytic T-lymphocyte precursors by defined stimuli. Immunology 1988:64:129-34.

82 Chrysofakis G, Tzanakis N, Kyriakoy D, et al. Perforin expression and cytotoxic activity of sputum CD8+ lymphocytes in patients with COPD. Chest 2004; 125:71-6.

83 Kasahara Y, Tuder RM, Cool CD, et al. Endothelial cell death and decreased expression of vascular endothelial growth factor and vascular endothelial growth factor receptor 2 in emphysema. Am J Respir Crit Care Med 2001; 163:737-44.

84 Kasahara Y, Tuder RM, Taraseviciene-Stewart L, et al. Inhibition of VEGF receptors causes lung cell apoptosis and emphysema. J Clin Invest 2000;106:1311-9.

85 Yokohori N, Aoshiba K, Nagai A. Increased levels of cell death and proliferation in alveolar wall cells in patients with pulmonary emphysema. Chest 2004; 125:626-32.

86 Enelow RI, Mohammed AZ, Stoler MH, et al. Structural and functional consequences of alveolar cell recognition by CD8(+) T lymphocytes in experimental lung disease. J Clin Invest 1998;102:1653-61.

87 Retamales I, Elliott WM, Meshi B, et al. Amplification of inflammation in emphysema and its association with latent adenoviral infection. Am J Respir Crit Care Med 2001;164:469-73.

88 Zhu JIE, Qiu YS, Majumdar S, et al. Exacerbations of bronchitis, bronchial eosinophilia and gene expression for interleukin-4, interleukin-5, and eosinophil chemoattractants. Am J Respir Crit Care Med 2001;164:109-16.

89 Hadida F, Vieillard V, Mollet L, et al. Cutting edge: RANTES regulates Fas ligand expression and killing by HIV-specific CD8 cytotoxic T cells. J Immunol 1999; 163:1105-9.

$90 \mathrm{Kim}$ JJ, Nottingham LK, Sin Jl, et al. CD8 positive T cells influence antigenspecific immune responses through the expression of chemokines. J Clin Invest 1998;102:1112-24.

91 Saetta M, Mariani M, Panina-Bordignon P, et al. Increased expression of the chemokine receptor CXCR3 and its ligand CXCL10 in peripheral airways of smokers with chronic obstructive pulmonary disease. Am J Respir Crit Care Med 2002; 165:1404-9.

92 Taub DD, Ortaldo JR, Turcovski-Corrales SM, et al. Beta chemokines costimulate lymphocyte cytolysis, proliferation, and lymphokine production. J Leuk Biol 1996;59:81-9.

93 Loetscher P, Seitz M, Clark-Lewis I, et al. Activation of NK cells by CC chemokines. Chemotaxis, $\mathrm{Ca}^{2+}$ mobilization, and enzyme release. J Immunol 1996;156:322-7.

94 Saetta M, Di Stefano A, Maestrelli P, et al. Airway eosinophilia and expression of interleukin-5 protein in asthma and in exacerbations of chronic bronchitis. Clin Exp Allergy 1996;26:766-74. 
95 Lams BE, Sousa AR, Rees PJ, et al. Immunopathology of the small-airway submucosa in smokers with and without chronic obstructive pulmonary disease. Am J Respir Crit Care Med 1998;158:1518-23.

96 Pesci A, Balbi B, Majori M, et al. Inflammatory cells and mediators in bronchial lavage of patients with chronic obstructive pulmonary disease. Eur Respir J 1998;12:380-6.

97 Yamamoto C, Yoneda T, Yoshikawa M, et al. Airway inflammation in COPD assessed by sputum levels of interleukin-8. Chest 1997;1 12:505-10.

98 Gursel G, Turktas H, Gokcora N, et al. Comparison of sputum and serum eosinophil cationic protein (ECP) levels in nonatopic asthma and chronic obstructive pulmonary disease. J Asthma 1997;34:313-9.

99 Saetta M, Baraldo S, Corbino L, et al. CD8+ve cells in the lungs of smokers with chronic obstructive pulmonary disease. Am J Respir Crit Care Med 1999; 160:711-7.

100 Warringa RA, Mengelers HJ, Raaijmakers JA, et al. Upregulation of formylpeptide and interleukin-8-induced eosinophil chemotaxis in patients with allergic asthma. J Allergy Clin Immunol 1993;91:1 198-205.

101 Warringa RA, Schweizer RC, Maikoe T, et al. Modulation of eosinophil chemotaxis by interleukin-5. Am J Respir Cell Mol Biol 1992;7:631-6.

102 Brightling CE, McKenna S, Hargadon B, et al. Sputum eosinophilia and the short term response to inhaled mometasone in chronic obstructive pulmonary disease. Thorax 2005:60:193-8.

103 Pizzichini E, Pizzichini MM, Gibson P, et al. Sputum eosinophilia predicts benefit from prednisone in smokers with chronic obstructive bronchitis. Am J Respir Crit Care Med 1998; 158:1511-7.

104 Chanez P, Vignola AM, O'Shaugnessy T, et al. Corticosteroid reversibility in COPD is related to features of asthma. Am J Respir Crit Care Med 1997:155:1529-34.

105 Fabbri LM, Romagnoli M, Corbetta L, et al. Differences in airway inflammation in patients with fixed airflow obstruction due to asthma or chronic obstructive pulmonary disease. Am J Respir Crit Care Med 2003; 167:418-24.

106 Sommerhoff CP, Caughey GH, Finkbeiner WE, et al. Mast cell chymase. A potent secretagogue for airway gland serous cells. J Immunol 1989; 142:2450-6.

107 Grashoff WF, Sont JK, Sterk PJ, et al. Chronic obstructive pulmonary disease: role of bronchiolar mast cells and macrophages. Am J Pathol 1997:151:1785-90.

108 Pesci A, Rossi GA, Bertorelli G, et al. Mast cells in the airway lumen and bronchial mucosa of patients with chronic bronchitis. Am J Respir Crit Care Med 1994; 149:1311-6.

109 Muller NL, Staples CA, Miller RR, et al. "Density mask". An objective method to quantitate emphysema using computed tomography. Chest 1988;94:782-7

110 Gurney JW, Jones KK, Robbins RA, et al. Regional distribution of emphysema: correlation of high-resolution CT with pulmonary function tests in unselected smokers. Radiology 1992;183:457-63.

111 Godfrey S, Edwards RH, Campbell EJ, et al. Repeatability of physical signs in airways obstruction. Thorax 1969;24:4-9.

112 Spiteri MA, Cook DG, Clarke SW. Reliability of eliciting physical signs in examination of the chest. Lancet 1988;1:873-5.

113 Gelb AF, Gold WM, Wright RR, et al. Physiologic diagnosis of subclinical emphysema. Am Rev Respir Dis 1973;107:50-63.

114 Petty TL, Silvers GW, Stanford RE. Mild emphysema is associated with reduced elastic recoil and increased lung size but not with air-flow limitation. Am Rev Respir Dis 1987; 136:867-71.

115 Wolkove N, Dajczman E, Colacone A, et al. The relationship between pulmonary function and dyspnea in obstructive lung disease. Chest 1989;96:1247-51.

116 Knudson RJ, Bloom JW, Knudson DE, et al. Subclinical effects of smoking Physiologic comparison of healthy middle-aged smokers and nonsmokers and interrelationships of lung function measurements. Chest 1984;86:20-9.

117 Knudson RJ, Knudson DE, Kaltenborn WT, et al. Subclinical effects of cigarette smoking. A five-year follow-up of physiologic comparisons of healthy middle-aged smokers and nonsmokers. Chest 1989;95:512-8.

118 Sansores RH, Pare PD, Abboud RT. Acute effect of cigarette smoking on the carbon monoxide diffusing capacity of the lung. Am Rev Respir Dis 1992; 146:951-8

119 Watson A, Joyce H, Hopper L, et al. Influence of smoking habits on change in carbon monoxide transfer factor over 10 years in middle aged men. Thorax 1993;48:119-24.
120 Gelb AF, Schein M, Kuei J, et al. Limited contribution of emphysema in advanced chronic obstructive pulmonary disease. Am Rev Respir Dis 1993; 147:1157-61

121 Gelb AF, Hogg JC, Muller NL, et al. Contribution of emphysema and small airways in COPD. Chest 1996;109:353-9.

122 Hale KA, Ewing SL, Gosnell BA, et al. Lung disease in long-term cigarette smokers with and without chronic air-flow obstruction. Am Rev Respir Dis 1984;130:716-21.

123 Tanino M, Betsuyaku T, Takeyabu K, et al. Increased levels of interleukin-8 in BAL fluid from smokers susceptible to pulmonary emphysema. Thorax 2002;57:405-11.

124 Kelly CA, Kotre CJ, Ward C, et al. Anatomical distribution of bronchoalveolar lavage fluid as assessed by digital subtraction radiography. Thorax 1987;42:624-8.

125 Martin TR, Raghu G, Maunder RJ, et al. The effects of chronic bronchitis and chronic air-flow obstruction on lung cell populations recovered by bronchoalveolar lavage. Am Rev Respir Dis 1985;132:254-60.

126 Maestrelli P, Saetta M, Di Stefano A, et al. Comparison of leukocyte counts in sputum, bronchial biopsies, and bronchoalveolar lavage. Am J Respir Crit Care Med 1995; 152:1926-31.

127 Belda J, Hussack $P$, Dolovich $M$, et al. Sputum induction: effect of nebulizer output and inhalation time on cell counts and fluid-phase measures. Clin Exp Allergy 2001;31:1740-4.

128 Donaldson GC, Seemungal TAR, Bhowmik A, et al. Relationship between exacerbation frequency and lung function decline in chronic obstructive pulmonary disease. Thorax 2002;57:847-52.

129 Fujimoto K, Yasuo M, Urushibata K, et al. Airway inflammation during stable and acutely exacerbated chronic obstructive pulmonary disease. Eur Respir J 2005;25:640-6.

130 Patel IS, Seemungal TA, Wilks M, et al. Relationship between bacterial colonisation and the frequency, character, and severity of COPD exacerbations. Thorax 2002;57:759-64.

131 White AJ, Gompertz S, Bayley DL, et al. Resolution of bronchial inflammation is related to bacterial eradication following treatment of exacerbations of chronic bronchitis. Thorax 2003;58:680-5.

132 Monso E, Rosell A, Bonet G, et al. Risk factors for lower airway bacterial colonization in chronic bronchitis. Eur Respir J 1999;13:338-42.

133 Hill AT, Campbell EJ, Hill SL, et al. Association between airway bacterial load and markers of airway inflammation in patients with stable chronic bronchitis. Am J Med 2000;109:288-95.

134 Banerjee D, Khair OA, Honeybourne D. Impact of sputum bacteria on airway inflammation and health status in clinical stable COPD. Eur Respir 2004; 23:685-91.

135 Hurst JR, Wilkinson TMA, Perera WR, et al. Relationships among bacteria, upper airway, lower airway, and systemic inflammation in COPD. Chest 2005; 127:1219-26.

136 Bresser $\mathbf{P}$, Out TA, van Alphen L, et al. Airway inflammation in nonobstructive and obstructive chronic bronchitis with chronic Haemophilus influenzae airway infection. Comparison with noninfected patients with chronic obstructive pulmonary disease. Am J Respir Crit Care Med 2000; 162:947-52.

137 Wilkinson TMA, Patel IS, Wilks M, et al. Airway bacterial load and FEV decline in patients with chronic obstructive pulmonary disease. Am J Respir Crit Care Med 2003; 167:1090-5.

138 Wedzicha JA. Airway infection accelerates decline of lung function in chronic obstructive pulmonary disease. Am J Respir Crit Care Med 2001; 164:1757-8.

139 Rennard SI, Daughton D, Fujita J, et al. Short-term smoking reduction is associated with reduction in measures of lower respiratory tract inflammation in heavy smokers. Eur Respir J 1990;3:752-9.

140 Willemse B, ten Hacken N, Rutgers B, et al. Association of current smoking with airway inflammation in chronic obstructive pulmonary disease and asymptomatic smokers. Respir Res 2005;6:38.

141 Turato G, Di Stefano A, Maestrelli P, et al. Effect of smoking cessation on airway inflammation in chronic bronchitis. Am J Respir Crit Care Med 1995; 152:1262-7.

142 Domaga A, Kulawik J, Maskey Warzechowska M, et al. The cellular composition and macrophage phenotype in induced sputum in smokers and ex-smokers with COPD. Chest 2003;123:1054-9. 